«Keruen» scientific journal

M.O.Auezov Institute of Literature and Art

ISSN 2078-8134

Volume 73, Number 4 (2021)

IRSTI 17.09.91

\author{
${ }^{1}$ Zh. Sarsenbaeva*, ${ }^{2}$ A.Yakici \\ ${ }^{1}$ Al-Farabi Kazakh National University and M.O.Auezov Institute of Literature and Art, \\ Almaty, Kazakhstan \\ ${ }^{2}$ Gazi University, Ankara, Turkey \\ 1E-mail: baden.zhansulu@gmail.com; 2e-mail: yakiciali@gmail.com; \\ ${ }^{1}$ ORCID: 0000-0002-9554-163X; ${ }^{2}$ ORCID: 0000-0001-9461-7324
}

\title{
The image of women in modern kazakh prose and psychological aspects in creating them
}

\begin{abstract}
The article analyzes the social problems of modern Kazakh prose, in particular the microthematic works of such famous writers as R.Mukanova, M.Omarova, L.Konys, universal values, ways of conveying the inner experiences of the protagonist in fiction, i.e. the problem of psychology.

The works of these authors in a small genre, depicting social contradictions, human nature, the inner world and the transformation of a woman, the language of characters, storylines, contradictions of thoughts and actions, the words of characters, their own stylistic features in the description of psychological phenomena.

Famous writers of the era of independence Rosa Mukanova, Madina Omarova, Lira Konys enriched Kazakh fiction with small works of epic genres, both in content and in changing form, which can be used to depict new content. In their stories, they try to resolve philosophical knots in their work, describing the psychology of women and various aspects of human life.

A common feature of the creativity of all three writers is that they are able to fully reveal the inner world of their characters and describe them in a way that touches the heart of the reader. He not only describes but also uses various artistic details. At the same time, psychology plays an important role in making the reader feel as deep as possible in order to influence their heart more strongly.

When defining the image of women in modern Kazakh prose and the psychological aspects of their creation, the skills of writers, stylistic features were used, in particular, methods of objectanalytical analysis, comparative analysis, systematization, abstracting, comparative and complex analysis.
\end{abstract}

Keywords: author, text, psychologism, dialogue, monologue, narrator.

Introduction. Modern Kazakh literature is a complete and innovative literature both in content and form, also in terms of ideological and artistic point of view. Since the independence years Kazakh literature has changed for the better and there were opened ways for new phenomenas. And nowadays, Kazakh writers got rid of totalitarianism and gained freedom. Along with independence our writers gained full freedom of speech (Orda, Kudaibergenov, Sarsenbayeva, Amanzhol, Mursalimova, 2019: 3).

The study of literature of this period is a complex and multifaceted phenomenon. It should be noted that after gaining independence several sectors or genres came into the literature, each of which had own search and novelty. The development of literature was also influenced by the prohibition of censorship and the opportunity to get acquainted with the primary research works in foreign literature. Well-known writers Roza Mukanova, Madina Omarova, Lira Konys enriched Kazakh fiction prose through their small-scale works of epic genre in terms of content changes 
and form changes that can be used to depict these very contents. In their stories they try to solve philosophical knots that describe various aspects of female psychologism and human life

A common feature of works by all three writers that they could reveal the inner world and soul of their characters and could describe in a creative way to reach the heart of each reader. They used creative way and various artistic details to give the image of characters in whole. At the same time psychologism is of great importance in order to excite the reader as deeply as possible, to have a stronger influence on their soul and heart.

Writer Mukhtar Auezov noted that "putting psychologism completely to the side means less, nothing but hollow words, as wild passages of primitive people"... so, psychologism has a special importance in the artistic depiction of the inner world and spiritual life of the hero, and the causes and consequences of each of actions (Pirali, 2007).

The problem of psychologism appears in the literature of Western Europe in the second half of the XVIII century, in the era of sentimentalism, in which epistolary and diary forms became especially popular. Eventually, at the end of the XIX century, a special psychological school was formed in Western European and Russian literary criticism. Its prominent representatives in Germany: W.Wundt, W. Wez, I.Folkelt, in France S.M. Girarden, E. Enneken. And for the development of psychological school in Russia A.A.Patepnya, D.N. Ovsyaniko-Kulikovsky, A.G. Gornfeld, V.I. Xarziev, V.A. Lezin the works of scientists such as were influential.

In the early twentieth century. Z.Freud and K. Under the influence of Jung's works, the deep psychology of personality began to take shape in the works of art (Freud, 1989), (Jung, 2007).

Also, the problem of psychology in Russian literary criticism of the twentieth century. V.Bursov (Bursov, 1979), L. Vygotsky (Vygotsky, 1968), L. Ginzburg (Ginzburg, 1977), D. Lixaghov (Lixaghov, 1968), I. Starachov (Starachov, 1973), A. Skaftymov (Skaftymov, 1972) was studied in the works of scientists, and the psychology of the character in the works of Russian classics was widely studied.

Methods. In determining the image of women and psychological aspects of representing them in modern Kazakh prose the skill aspects and stylistic features of writers, in particular, methods of object-analytical analysis, comparative analysis, systematization, generalization, comparative and complex analysis were used.

During the topic study courses the collective monographs developed by the scientist G. Prali and scientists of the Institute of literature and art named after M. O. Auezov, as well as works on issues of psychologism in artistic work, were taken as a basis.

Results. In modern Kazakh prose, a writer R. Mukanova distinguishes with her talent and focuses on topics based on national spirit, the modern image of the Kazakh woman, environmental issues, the creative laboratory, and the artistic world of the writer.

Results. Writer R. Mukanova, who in modern Kazakh prose was distinguished by bright pepper, composed topical topics about the national spirit, the modern image of the Kazakh woman, environmental issues, a creative laboratory, and the artistic world of the writer. "P. Mukanova's specific personality is to portray a development of internal psychological struggle via unconscious actions of the characters and describe their mental world, along with deep examining of fantasy realm. Almost all compositions of writer's story are about loneliness of personages' life who are in trouble" (The literature of XXI century, 2012: 169).

The role of psychopoetics in fiction is special. "The artistic and aesthetic function of psychopoetics determines the main features of fiction. Since fiction genre also depicts the realities of human life and human society, every writer is free to use a psychopathic visual tool" (Dudebayev zh., Bissenbayev P., Karibozov E., 2016: 36). Considering psychopoetics in the stories by the writer Rosa Mukanova it can be noted that the connection between the soul and body of a person, describing internal state, suffer, sadness and joy are determined by artistic and aesthetic functions.

Writer Madina Omarova's creation is expectedly in the list of works describing the women image in modern Kazakh literature. Hershort works are also full of philosophical depth and poetic artistry. Madina Omarova's prose is full of mysteries, many of which contain elements of the 
Gothic style. These works not limited just effecting upon the reader's thought, but also give them aesthetic pleasure and lend wings to their imagination.

With her works, Lyra Konyss has created the edge of art with excellent genre, style, nature through philosophical reflections that briefly and accurately convey the fate of young people. Her artistic world is distinguished by her works which are built on dialogues, monologues filled with psychological contradictions, unique relationships between a ghost and an ordinary living character, also associated with fairy tales.

Discussion. One of the works by writer Rosa Mukanova is the story "Tul - A widow" which narrates about the features of a modern Kazakh woman. The woman image in Kazakh literature of the beginning of the XX century is depicted as constrained, having no freedom of choice, defenseless and always having hard fate one, on the other hand a work by Rosa Mukanova that describes a dragon lady who dominates all around, so no one can take advantage of her, also she was acting as rough man.

The main meaning of the story's nominative name: "Tul (adj.) - A widow is a woman whose husband has died or divorced, childless" (Malbakov M., Yessenova K., Khinayat B., 2011). The main hero in this story doesn't deserve the real widow name, as she was alone because her husband left her for another woman, also she had a child. Nevertheless, the main character following the current course of the century forgot about her weak nature, her existence and feels lonely.

In this story the writer narrates psychological-emotional condition and mental state of a bad tempered, savagery and profit-driven woman who was thinking only of wellbeing and forgot about bluebird of happiness in her hand. As she was thinking only providing for a family and forgot that she is a woman with exquisite beauty and because of hard work she became a masculine woman. This woman's tragedy is nowadays common human problem.

Gulsia Pirali is a scientist who studied the problem of psychologism in literary criticism noted the followings: "Describing the inner feeling through the systems of speech and thought is a direct approach (the inner universe) and the second is an indirect approach (the outer universe) meaning that the processes in the psyche and consciousness of the hero are not directly reflected, but only through external actions, facial or other mimic movements of the body, or external expressions that defined by appearances." (Pralieva, 2003: 85). According to this statement of the scientist, here we can note that the writer Roza Mukanova's story shows that she was able to describe both the direct approach (the inner universe) and the indirect approach (the outer universe) in relation to each other.

In the narrative system of the story an event description is exchanged between the authornarrator and the character's monologue which clearly expressed character's internal psychological state.

The hero once said: "Here should be another reason... Why did my husband, with whom we have been married for thirty years decided to leave me? Why he was so eager to stay away from home, to seek refuge and to be alone ...? Tired... How come? Is it my fault? Because of my evil character? No, he wanted tto start a different life. He wanted to be happy... If he thinks it was unfortunate that he was my partner and we were unhappy couple? Impossible..."- she was talking to herself trying to understand how all these happened to her. And the author-narrator uses the following narrative form to captivate this state of the character to give the plot further emotional and expressive tone: "- She went ballistic. Crawled and laid down on the soft fur carpet, curled up. She was nursing her knees and tried to cry, but there were no tears in her eyes. Now she wanted to raise a bowl, maybe just wanted to mourn. No way! Mourning a living person, a happy person is something that is not in superstition. It was her soul crying out ... She was groaning and rolling over as confessing her guilty and the situation that she became a widow was hard. She felt as if someone had come and poisoned her and continued roll over as if she was going to die. Being unable to find answers to many questions in her mind, she uttered with different sounds. Nothing changed" (Mukanova R., 2008: 50). In a later plot the problem becomes more acute: "Suddenly she got buzzed her hair in a rush. And came close to the mirror saying that "This is a real widow. The inside and outside should match. Inside fear should be on the outside as well. In order to live 
being invisible in the public it is necessary to have such a look for yourself. And only then people will understand the meaning of widow's suffer, widow's life. Now I'm a real widow" saying this she was crying looking at herself in the mirror (Mukanova R., 2008: 52). On these lines the author inspires the reader by one character's life story. The family has its own duties which means a father and a mother have their own responsibilities in the family to perform. There is no doubt that if duties are changed between them then a complete change would take place among whole human. Aiming to earn more money and being busy at markets many women forget to care themselves and this is the real tragedy of nowadays.

Researcher A. Kalieva notes that "Almost all works by the writer in genre of short stories, describe the terrible fate of people who are depressed by the loneliness of life" (The literature of the XXI century, 2012: 169). In fact, in the story we have reviewed the writer R. Mukanova psychologically describes the fate of an depressed woman, skillfully demonstrates the fate of women in modern Kazakh society, their changes in the soul and body, and the complication of the human essence.

Almost all works by the writer Rosa Mukanova show the realities of our time. In her works she was able to deliver the tragic difficulties of the whole time through the image of a modern Kazakh woman. The story "Eternal child face" written by the writer also falls into this category of work. The main feat of the work is that its theme and idea were the result of the fact that the atomic bomb, committed from the hands of mankind in history, was tested on Kazakh soil. The main features of the work are theme and idea that masterfully reflect the consequences of the atomic bomb test on the Kazakh land, and devastating disaster created by human hands in history.

The story is based on the fate of a girl, Laila, who became disabled due to an atomic bomb test and cannot grew having a small childish face forever. There is every reason to believe that the real prototype of the hero is many Kazakhs who suffered from the atomic test site at the Semey city. Even knowing the Laila image who has been surrounded only with deprivation and ridicule we wonder if her image can be whole Kazakh nations' image who has been dependent on other's rule for years, seeing oppression, and even has lost own mentality, forgot native language, and religion

The story not only raises such a pressing problem, but also expressively and artistically depicts poetic power. The ancient cosmogonic myths of the Kazakh can be seen within lines that the hero Laila always accompanies the Bright Moon. If we pay attention to the myths related to the moon in Kazakh folklore, the moon appears once as a bride, once as a girl, and sometimes is depicted as a human companion.

Layla, with her heavy heard and fate felt that only the Moon can understand and sympathize to her: "Oh, the Bright Moon, no need for a speck of sympathy. I'm a sinless girl. I have feelings and sound in mind. But my heart is full of revenge and horror in this life and the world in whole. I am a human being, but all others see me only as a disabled person like reminding them to call to repent" saying these she feels lonely among people and can only bare her soul when she talks to the Moon. Through the dialogue of the hero with the Moon the author delivers the followings: "Every time when Karauyl people see me they say, "Allah created her to remind people that they have to do true repentance and be thankful for their health, for well-being of their sound body." Is it so, the Bright moon? I trust you and only believe in you. At least I hope you can live up to my hopes. Then what are these people will saying? And who am I? Is it forever? Is it really a child face forever?" saying these she expresses confidence in the Moon (Mukanova R., 2008: 3).

From this story one can understand the psychological imaging means that we take as a basis of this topic. In the above-mentioned work by the scientist Gulziya Prali the psychological imaging means are classified as follows:

"The first is the "direct" ("direct") type of psychological representation which is the perception of the character's soul from the artistic cognition point of view, that is, the psychological analysis through the inner word, the form of utterances (replicas), self-control, mental imagination, internal monologue, memory and imagination, etc. 
The second is the emphasis on external psychological gestures-manifestations in the transmission of the psyche - nonverbal gestures, the use of other forms of them.

The third is an author's psychological narrative method that summarizes these two approaches "(Piraliev, 2003). The first of the listed means includes the fact that Laila shared her secrets with the Moon, also the author skillfully used the second and third means in the following linesways: "A Layla girl cannot gain patience for the body of a disabled person.

"Layla girl was not able to keep calmness in her disabled body and feverish anger covered her, so she trembled in every limb. If she feels someone looking to her hands and legs, she cannot find a place to hide herself. She was begging no one to notice her excessively enlarged old hands and imperfect legs. And Katira deliberately gave a freezing glance, stared in disgust at her as if she wanted to strike her painful chord. Such cases drove Laila-girl up the wall" (Mukanova R., 2008).

The author skillfully combined the exposition and the prologue of the story. At the beginning of the story, Laila who was a close friend of the Moon, and only the Moon, which was kind to her, is described as left this world together with her at the moment of her death. The writer concludes this moment as following: "The Moon has long been circling the image of the yielded up life girl, and suddenly moved away. As said goodbye forever" (Mukanova R., 2008).

This story by Rosa Mukanova is based on a tragic event in Kazakh history, and ner next story is based on the image of historical figures.

Despite the fact that in Kazakh literature we often meet voluminous epic works depicting Genghis Khan, the image of Genghis in the genre of a small story is very rare. We show here the heroes of the story "Kudiet-Kie" by Roza Mukanova: Genghis Khan, his mother is Oleng-sheshe (mother) and his brother Khasar. All these characters are historical figures. All these characters are historical figures. There is also evidence that they were in real history, that they has such names.

In the course of the story, Genghis Khan and his brother Khasar have quarreled, thus their mother regretted that relationship between her two children damaged and did her best to unite their relationship. In the course of the story the inner psychological state of the mother who is upset for her children is described very effectively.

From the point of view of the artistic reality and the reality of life in the work there is evidence that in real life there was a quarrel between Genghis Khan and his brother Khasar. Nevertheless, one thing that will surprise any reader of the story is that the poem narrates that Olen-sheshe does 5 times pray, and portrays Genghis Khan as an infidel. Although there is no reliable evidence of Genghis Khan's involvement in the Islamic religion, but much is known about his divine (theological) position. From this point of view, this decision of the author can be interpreted as an allusion.

One of the psychological aspects encountered in the story is Genghis Khan's dream.

"The plot of the dream is figuratively and symbolically forms the psychological motive, instinctual desires, demands, emotions, feelings of the dreamer, and a variety of psychological complexes in the subconscious " - concluded the author through Genghis Khan's dream. This shows that the intention to hurt his mother and quarrel with his brother was not in the subconscious (Piralieva, 2003: 91). "Genghis Khan was suffocating and woke up scared. "Oh, no" he said to himself. "I had a terrible dream - and looked around in horror. - As the Almighty is sacred. The Almighty is sacred... And my lord gave birth to me. I think this lord is my mother Olen-sheshe." Genghis Khan opened his eyes widely as a deer in the headlights and called to mind his dream again" these lines vividly describes the helplessness of the powerful khan who ruled over the half of the world in front of another Almighty (Mukanova R., 2008).

In this story the author described in detail the internal psychological state in the narrative system and revealed the character of Olen-sheshe. While reading the work we can assume that the author skillfully used in describing Olen-sheshe's internal state a method of describing in connection with the nature part as in the above-mentioned story "Eternalchild face." 
This time, the author connects the hero with the wind, that is, the hero talk to a piece of nature - to the wind: That night the wind blew for a long time. Olen-sheshe opened the chariot's door and listened to the bleak wind. And it seems the wind whispered to her" (Mukanova R., 2008: 55). In this very plot of talk between the hero and a wind that the poem clearly shows the inner turmoil, anxiety and sorrows of Olen-sheshe.

The main topic of conversation is here - a Mother. Motherhood. A maternal feeling. The hero of the story tells about Olen-sheshe's maternal feeling for her children, and the fact that everyone is born from a mother, so even a powerful Genghis Khan who is ruling the world bowed his head in front of his mother. The story tells that the ruler who conquered the whole world cannot be only a ruler for own mother, but also he remains as a child for his mother, and shows the Godgiven power to a mother.

One of the works by R. Mukanova is the story "Kuna - Sin", a story about hard female fate, psychological feelings. The plot lines take place at night, and there are three main characters Gulbaram who gave a birth to a child, a tokal-second wife who killed the child, and Ak Bayan - a witness who saw all happened. Here it should be noted that the author described the nature in a special way. The image of nature is accurately depicted in continuity with the inner world of the characters. "The sunrise was in fear and trembling. What a pale morning it was that day. It looked through the three helpless who were standing there covered in sins around their neck, and they would be punished hearing own crying voice" (Mukanova R., 2008: 55). Ak Bayan is Abylkasim's bride who is known for his wealth. Her sister-in-law Gulbaram becomes pregnant being not married and agrees to kill her child at night, and a tokal (second wife) who is afraid of people's gossip as "dishonor and brings shame on family" and Abylkasym to become angry, kills the newborn baby by pouring copperas into his mouth.

Sin wears the consciousness of the old woman and does not dry the tears of both eyes. All life goes in tears.. And the paintings of Gulbaram and Ak Bayan will be widely described.

For the next fifty years, the sin of that night deeply touched Ak Bayan's soul, as taking the life of an innocent child is the the worst of sins. This sin destroyed the old woman's consciousness and she couldn't help to stop tears from her two eyes. She spent her whole life in tears. In the story, the author does not delve into bloodstained tokal's inner world, just drawing her actions, revealing their severity. But Gulbaram's and Ak Bayan's heartache and hurt of inner world are described in detail. Gulbaram was alone for the rest of her life, she had a childless, unhappy life. Ak Bayan also was begging forgiveness from the God for her sin and spent the rest fifty years crying every time. There is no meaning in the life of two who were punished in the name of the innocent child. Fifty years have passed since the sins of youth, passion, and childhood took place, and the country has been renewed for many times, but every bright morning reminds that night and make them ashamed.

In the story, the "battle of ding-dong fight" between a Day and a Night is as never-ending battle between good and evil. In fact, the mellow night also has its own beauty. But the night in the story is associated with the death of an innocent child, the sin of women, and is given as a witness and a sign of serious sinfulness. Gulbaram and Ak Bayan's life turned into a dark night same as that very night. In our minds the night is a place of darkness, pitch dark, black matter. A dark night when there happened a grave sin, a cut of human life, a murder which is the worst of sinsis a sin of sin. They wanted to get rid of suffering a little bit and leave the sin in that pitch dark. As they know in the morning the painful day begins again. The night makes the old woman feel worse by aggravating factors of her sin. A night measures with a suffer, a sin, while a morning is pure and innocent.

In our opinion, the author consciously did not reveal the inner world of tokal who directly killed the baby. She is easily poured a copperas into the baby's mouth. It was nothing for her to commit a crime without thought, and she even was not in sorrow. It is unlikely that such a person will suffer or fell any sorrow in the soul. Tokal's cruelty is reflected in her words. Tokal disguised the death of a child with a false conscience, so the notions of holy and sin are alien. then it is impossible to expect anything else from tokal. Although Gulbaram was ruled by her passions and 
agreed for a death of the baby, Ak Bayan was horrified at this decision, shaked both hands and was thick of speech as if she lost her mind. Tokal immediately managed to hide evidences of the crime without thinking and without regaining consciousness to anyone. Everything happened in a short time. Ak Bayan who was begging forgiveness all her life was hope for amnesty only from Allah. They say that to meet own sins saves a person from suffering and purifies a soul. So, once at dark night a feeling and living in bitterness woman came to her mother in search of graces. The nightmare was over, and she was in a state of shock. That night she was worry too much and trembling said followings "Oh, mother, there is a severe penalty on me. Oh, poor me, the God won't be merciful to me."

- Oh, no! What's the matter, what is happened else? Oh my God - shouting these a mother was going around a chimney and felt as losing her mind. She wanted to clear up her mystery full of sins and try to make up a good excuse.

- Oh, my God, you are a bad lot. What are you talking about? What are you talking, you are pathetic woman? Who did kill a baby? If you killed a baby, you will never be sated in life. Killing a human being is an egregious sin. Killing a human being is the worse sin... Mukanova R., 2008: 52). Both Ak Bayan and Akmaral being childless means - they were damned by an innocent child! In this story several things found their description as followings: a morning is a bringer of a future, a second wife characterizes cruelty and severity, and a night is a sign of sin and crime. If the sinners would recompense for their sins? Of course. Ak Bayan has an indirect bearing upon happened case that night, but she was the witness of the case. Since then, even though almost fifty years passed, she was never laughing, even smiling. Gulbaram also was sobbing violently: "She was married to her lovey, unfortunately was childless. "Oh, if only I could have a child. My dear sister-in-law, I'm such a sinner and never would given such a chance".

In the course of the story, the author was able to convey in detail the painful fate of women and the social inequality, as well as the importance of the continuation of generations, and the fact that the sin committed on earth will taste hard punishment.

When talking about the Gothic style in Kazakh literature, one of the most famous writers should be mentioned is M. Omarova, and it is not difficult to recognize the biographical author's image within her narrative form of the story, a mini-novel. Another feature of her works is that the character appears in the image of a narrator and is based on the narrative from the first person.

It is not difficult to see such elements in the short novel "Ana ghumyr". This work describes the whole life of a woman from her childhood and marriage years. Despite the small volume of the work, the author skillfully covered series of events of different time and places.

This mini-novel by the author consists of small chapters. The women in these chapters were suffering from loneliness, nobody caress in the childhood and in the family, but they were kind and honest. In the section "Kazakh kyz" the author tells about her childhood and narrates about a widowed mother who raised five children by herself, so this situation influenced and her mother became a woman of courage with enduring disposition. In this way, the writer tells about the different situations of mothers and about the features of Kazakh women, namely being patient, dignity, and kindness.

The author narrates a story about Galiya and skillfully describes the situation of girls who are alone in the society for the same reasons as for Galiya, namely they remain "alone" because of love, to abide by own promise, so they stayed single.

It also raises the question of the relationship between the mother and the child, the matter of a mother for her child's sake is on the main plane. It should also be noted that we can observe the change in the image of a woman, including a Kazakh woman, through the plots associated with alcohol in this work. And this work has the mystical lines inherent only in the author. We can see it in the following lines: "You. Yes, I'm talking to you. You came to us as a bride, but you are .... After you joined our family, we have only troubles, grief and sorrow you brought to this house. Now my son is died. You want to forget all these as nothing happened. No, you cannot, you can't escape. I will not get you leave in piece. And I won't let you go. You will live here with us since today. You will serve us, your father-in-law and me. You will be waiting for Zhangir in this house. 
Do you hear me? If you don't follow these sayings, I'll blast and curse you. If you don't do what I say, I'll cast a spell. I'll place a curse on you, you will be sealed to eternal damnation. So far, I was controlling myself as was afraid that my saying can touch the innocent baby Alken. But all people are equal, so he probably same deserves as my son. I don't feel sorry anymore. You will stay here today "(Omarova M., 2009). It is not difficult to recognize the psychology of the old-fashioned Kazakh woman through these lines. Reading the dialogue, the reader can only imagine a fierce, woody, old woman.

And this inner monologue of the protagonist not only testifies to the fact that the mother's heart is a sacrifice in the way of a child, but also brings to mind the most important world in life: It is said that a bald man gets his anger from a crane. Doesn't God see it? All I could hear was Alken talking. You will be able to protect my baby from copper. And in addition to the fact that the mother can sacrifice herself for her child's sake, this inner monologue of the main character brings to mind and limits the most important thing in life: "...How can she place a curse on me? What is my guilt here?" They say, "the stronger always blames the weaker". The God should see all these. I was just nervous with her speech about Alken. But I can protect my child from you, you devil woman. While I look at my son, I see my grandmother wearing snow white headwear and my mom living her thorny road of life. The continuation of life is the contribution of generation to generation. Now and on he should pass a spark from my heart into the bosom of one little angel. This is the law of life"(Omarova M., 2009).

Another story by Madina Omarova with a female character is "Gulshat". In a short work the fate of many Kazakh women and girls is depicted in the artistic, clear and unambiguous way. The psychology of the main character may seem strange at first glance. But as to read to the end, one can realize that she is thirsty for true feelings and cannot find love that would fill her entire body. Almost four months passed since she has married and joined a new family, but they cannot receive her into their family and she cannot feel confidence, too. Unfortunately, this situation is well known in many families in the Kazakh society. The author beautifully describes this issue in parallel with the childish love of a little girl.

The inner monologue of the hero through the flow of consciousness delivers the her inner pain: "I thought about Gulshat. A love. What is the love? Is it something that exists or not? A lifelong love. It is impossible to love during whole life. Maybe, this is a possible thing, but not everyone can do it. In principle, there is probably no such concept. It depends on the stability of the character of a woman or man. ... And for many, love is a beating of the heart a little more than usual, a feeling of passion, a desire for physical beauty or the beauty of being, a desire to own", these lines also determine the thought of the whole story (Omarova M., 2009). The bride can admit it and inspire it to herself. Only the author uses not only a monologue to reveal the inner psychological state of the character, but also turns a dialogue and a description of her actions. Therefore, there is more dynamics in the conversation than the verbiage.

Madina Omarova's works are focused on the modern world, the life and fate of today's contemporaries. The main principle of her works is the loneliness of characters in spite they live in the society, the discomfort in their lives, the lack of warmth to each other - in short, the image and life of the modern society. She describes all these both as in the everyday life and as in dramatic situations when events don't match to the usual order of life.

When creating an artistic image of a person in the literature, the writer describes the hero's image and actions in such a way that along with the typical features of the environment and the epoch, the internal features inherent only to hero's personality is clearly visible. The work reveals a person's personal attitude to life, worldview, and character in all aspects. Thus, the creative step in creating an image is based primarily on revealing the character of a person, his/her being. One of the next young writers who has created such simple but real life characters is Lyra Konys.

It is clear that Lira Konys is a talented lyricist. Her short stories included in the prose collection "Mangilik saghynysh" are full of longing. She skillfully outlines the past days, people who were nearby and now went into eternity by recalling their actions and masterfully narrates stories. Most of Lira Konys's stories are told from the first person 
The successful story of the young writer "Ghayip ul" has a weak plot, there is no clash of opinions nor conflict, no disposition, but just a narrative form with an attractive idea.

The theme of love, the concept of love takes a great place among romantics as the concept of the world, art and man. Creativity is a life condition for romantics. The world of feelings allows you to learn the space. In the work by Lyra, this motive also takes an important place in connection with space, their integration, mutual understanding. A number of Lyra's works included in the unique collection of prose are devoted to the love story. A sensitive girl could not stand to evade this topic. However, she raises public issues within the framework of the love topic.

Her characters are distinguished by their courtesy, truelove, vivid imagination, and extreme sensitivity. And her views on the world are original and here are some samples of her wise ideas: she says that talks about the honor are "comforting lies on a paper", "there are many who seek for the happiness, but happiness is limited", and "should to think on not when a man was created, but when is the end of the creation" (Konys L., 2013).

"She always sighed looking at her small hands. As she wants to embrace everyone" (Konys L., 2013). This is a beautiful image that easily describes the character. So, look at the following lines: "One of the people with whom she was so in love hit her by a car when she crossed the street in a hurry to her classes. There was a death in the car..."(Settlement L., 2013).

If you notice, in some of these paragraphs the author does not know when she has proceeded from backstage lyricism to sad sentimentalism. This is a real tenderness of a writer. Moreover, the plot is fictitious, and storytelling prevails over the narrative description. Therefore, despite interesting ideas the artistic quality of the work is not good as we expected.

The "Ertegi" story is told on behalf of one youth. There are two main heroes, and the the author managed to highlight the character of both of them. And this is expressed not in a long description, but in the words of the characters themselves, in actions. For example, the narrating girl has such assessments as "The old woman won't stand upon a coddle", "The old woman does not care" and these shows her attitude to her grandmother and therefore describes her spoiled rotten character.

The author describes the girl's state, who grew up pampered by her grandmother as followings: "She could not regain her temper, lay down till the evening and looked again in the mirror. There was a spark of courage in her eyes which flashes every time and when her pure world was collapsed the flash is gone, and now what she has is the injured and meaningless look. She believed in a fairy tale, often shared her secrets with Andersen, rode a fabulous eagle in her dream flying in the sky, braided hairs for Kunekei's. Since her grandmother has died, she stopped to believe in fairy tales." With these lines the author shows that yesterday's carefree girl said goodbye to her childhood (Konyc L., 2013).

There are various women images are created in other works by Lira Konys. The woman in this author's works is sometimes both brave and courageous, and sometimes sentimental. Sometimes it is a woman of solid frame with harsh character. And next time is known for her great knowledge and versatility. All this is the image of a modern Kazakh woman.

Conclusion. It should be noted that in small-scale works born in the independence years, the image of modern society, the problems of the people, and the scenes of the spiritually depraved times are reflected in the artistic and ideological, innovative research works. The features of creating a new image of the Kazakh woman in artistic prose in the literature of this period, the transformation of her her inner world, nature, and appearance change were also analyzed.

The work by R. Mukanova, M. Omarova, L. Konys was able to convey to the reader the image of a modern Kazakh woman, absorbing the national color of Kazakh literature, forming a new color in connection with the trends of world literature. Throughout their works that truly embodied characters, masterly and sincerely depicts their actions and inner world, and the essence of their stories, the complexity of the universe, the valuable thoughts about the human being have raised Kazakh literature and spirituality to a high level. 


\author{
1 Ж.Сәрсенбаева, ${ }^{2}$ А.Якыджы \\ ${ }^{1}$ Әл-Фараби атындағы Қазақ ұлттық университеті және М.О.Әуезов атындағы \\ Әдебиет және өнер институтының докторанты, \\ Алматы, Қазақстан; \\ ${ }^{2}$ Гази университеті, Анкара, Түркия \\ 1e-mail: baden.zhansulu@gmail.com; 2e-mail: yakiciali@gmail.com; \\ ${ }^{1}$ ORCID: 0000-0002-9554-163X, ${ }^{2}$ ORCID: 0000-0001-9461-7324
}

\title{
Қазіргі қазақ прозасындағы әйел образы және оларды сомдаудағы психологиялық аспектілер
}

Андатпа. Мақалада қазіргі қазақ прозасындағы, атап айтқанда, Роза Мұқанова, Мадина Омарова, Лира Қоныс секілді айтулы жазушылардың микросюжетті шығармаларында көрініс тапқан әлеуметтік мәселелер, жалпыадамзаттық құндылықтар көркем прозадағы кейіпкердің ішкі жан сезімін беру тәсілдері, яғни психологизм мәселесі талданады.

Аталған авторлардың әлеуметтік қайшылықтар, адам болмысы, нақтырақ әйел затының ішкі жан әлемі мен трансформациясы суреттелген шағын жанрдағы шығармалары объектіге алынып, кейіпкерлерінің сөйлеу тілі, сюжеттік желілер, кейіпкерлердің ойы мен іс-әрекетінің, сөзінің қайшылықтары, олардың психологиялық құбылыстарын суреттеудегі қаламгерлердің өзіндік стильдік ерекшеліктері анықталады.

Тәуелсіздік дәуірінде әдебиетте есімдері елеулі жазушылар Роза Мұқанова, Мадина Омарова, Лира Қоныс шағын көлемді эпикалық жанрдағы шығармалары арқылы қазақ көркем прозасын мазмұн жағынан да, сол жаңа мазмұнды бейнелеуде пайдаланар пішіндік өзгерістерімен де байытты. Олар өз әңгімелерінде дені әйел психологизмі мен адам өмірінің өзгеше қырларын суреттей отырып, шығармашылығындағы философиялық түйіндерді шешуге тырысады.

Аталған үш жазушының да шығармашылығына тән ортақ қасиет - олар өз кейіпкерлерінің ішкі жан әлемін тұтастай ашып, оқырманның жүрегіне жететіндей суреттей біледі. Тек жалаң суреттеп қана қоймай, әртүрлі көркемдік детальдерді пайдаланады. Сонымен қатар оқырманды мүмкіндігінше терең толғандыру, оның жан-жүрегіне неғұрлым күштірек әсер етуде психологизмнің мәні зор.

Қазіргі қазақ прозасындағы әйел образы мен оларды сомдаудағы психологиялық аспектілерді анықтауда жазушылардың шеберлік қырлары, стильдік ерекшеліктері, атап айтқанда объектілік-аналитикалық талдау, салыстырмалы талдау, жүйелеу, жинақтау, салыстырмалы және кешенді талдау әдістері қолданылды.

Кілт сөздер: автор, мәтін, психологизм, диалог, монолог, нарратор.

\section{${ }^{1}$ Ж.Сарсенбаева, ${ }^{2}$ Али Якыджы}

${ }^{1}$ Казахский национальный университета им. аль-Фараби и Института Литературы и искусства имени М.О.Ауэзова,

Алматы, Казахстан;

2 Университет Гази, Анкара, Түркия;

1e-mail: baden.zhansulu@gmail.com; 2e-mail: yakiciali@gmail.com

10RCID: 0000-0002-9554-163X, 20RCID: 0000-0001-9461-7324

\section{Образ женщин в современной казахской прозе и психологические аспекты их характера}

Аннотация: В статье анализируются социальные проблемы современной казахской прозы, в частности микротематические произведения таких известных писателей, как Роза Муканова, Мадина Омарова, Лира Коныс, общечеловеческие ценности, способы передачи 
внутренних переживаний главного героя в художественной литературе, т.е. проблема психологии.

Произведений этих авторов в малом жанре, изображающие социальные противоречия, человеческую природу, внутренний мир и преображение женщины, язык персонажей, сюжетные линии, противоречия мыслей и действий, слова персонажей, собственные стилистические особенности в описание психологических явлений.

Известные писатели эпохи независимости Роза Муканова, Мадина Омарова, Лира Коныс обогатили казахскую художественную литературу малый произведениями эпических жанров, как по содержанию, так и по изменению формы, которые можно использовать для изображения нового содержания. В своих рассказах они пытаются разрешить философские узлы в своей работе, описывая психологию женщины и различные аспекты человеческой жизни.

Общей чертой творчества всех трех писателей является то, что они способны полностью раскрыть внутренний мир своих персонажей и описать их так, как это затрагивает сердце читателя. Он не только описывает, но и использует различные художественные детали. В то же время психология играет важную роль в том, чтобы читатель почувствовал как можно глубже, чтобы сильнее повлиять на его сердце.

При определении образа женщин в современной казахской прозе и психологических аспектов их создания использовались навыки писателей, стилистические особенности, в частности, методы объектно-аналитического анализа, сравнительного анализа, систематизации, реферирования, сравнительного и комплексного анализа.

Ключевые слова: автор, текст, психологизм, диалог, монолог, нарратор.

Информация об авторе: Сарсенбаева Ж.Б. докторант Казахского начионального университета имени аль-Фараби и Институт Литературы и искусства имени M.O.Aуэзова. E-mail: baden.zhansulu@gmail.com; ORCID: 0000-0002-9554-163X, Scopus ID: 57210989139

Якыджы А., д.ф.н., профессор университета Гази, Анкара. е-таil: yakiciali@gmail.com, ORCID:0000-0001-9461-7324, Scopus ID: 38162506200

\section{Әдебиеттер:}

[1] Бурсов Б. Личность Достоевского. - Ленинград, 1979, - 680 с. (орыс).

[2] Выготский Л. Психология искусства. - Москва, 1968. - 345 с. (орыс).

[3] Гинзбург Л. О психологической прозе. - Москва, 1977. - 350 с. (орыс).

[4] Дәдебаев Ж., Бисенбаев П., Кәрібозов Е. Шыңғыс Айтматовтың психопоэтикасы. - // ҚазҰУ Хабаршысы, Филология Сериясы, 2016. - Том 159. - № 1. - 35-38 бб. (қаз).

[5] Қоныс Л. Шахарбанудың сыңсуы. - Алматы, 2013. - 192 б. (қаз).

[6] Лихачев Д. Внутренний мир художественного произведения. - Вопросы литературы, 1968. - №8. - С. 74-87. (орыс).

[7] Малбақов М., Есенова Қ., Хинаят Б. Қазақ әдеби тілінің сөздігі. Он бес томдық. 14-том. - Алматы, 2011. - 800 б. (қаз).

[8] Мұқанова Р. Шатыр астындағы Мен. Әңгімелер мен драма. - Алматы, 2008. - 285 б.

[9] Омарова М. Ана ғұмыр. Проза. - Алматы, 2009. - 126 б. (қаз).

[10] Orda G., Khudaibergenov N., Sarsenbayeva Zh., Amanzhol S., Mursalimova N. The December Revolt Statement (Description) in Kazakh Literature. - Opción, 2019. - Año 35, No.89. URL:http://www.scopus.com/inward/record.url?eid=2s2.085072153777\&partnerID=MN8TOAR

P. 179-194. (ағылш)

[11] Пірәлиева Г. Көркем прозадағы психологизмнің кейбір мәселелері (Түс көру, бейвербалды ишараттар, заттық әлем). - Алматы, 2003. - 258 б. (қаз).

[12] Скафтымов А. О психологизме в творчестве Стендаля и Толстого. - Москва, 1972. 288 с. (орыс). 
[13] Страхов И. Психологический анализ в литературном творчестве: В 2 ч. - Саратов, (1973). - Ч.1. - 183 с. (орыс).

[14] Фрейд 3. Введение в психоанализ. - Москва, 1989. - 456 с. (орыс).

[15] Юнг К. Сознание и бессознательное. - Москва, 2007. - 188 с. (орыс).

[16] XXI ғасыр әдебиеті.- Алматы: Арыс, 2012. - 640 б. (орыс).

\section{Литература:}

[1] Бурсов Б. Личность Достоевского. - Ленинград, 1979, - 680 с. (рус)

[2] Выготский Л. Психология искусства. - Москва, 1968. - 345 с. (рус)

[3] Гинзбург Л. О психологической прозе. - Москва, 1977. - 350 с. (рус)

[4] Дадебаев Ж., Бисенбаев П., Карибозов Э. Психопоэтика Чингиза Айтматова. - // Вестник КазНУ, Серия «Филология», 2016. - Том 159. - № 1. - С. 35-38. (каз)

[5] Коныс Л. Песни Шахарбануа. - Алматы, 2013. - 192 б. (каз)

[6] Лихачев Д. Внутренний мир художественного произведения. - Вопросы литературы, 1968. - №8. - С. 74-87. (рус)

[7] Мальбаков М., Есенова К., Хинаят Б. Словарь казахского литературного языка. Пятнадцать томов. - Алматы, 2011. -Т. 14 - 800 с. (каз)

[8] Муканова Р. Я под крышей. Рассказы и драмы. - Алматы, 2008. - 285 с. (каз)

[9] Омарова М. Материнская жизнь. Проза. - Алматы, 2009. - 126 с. (каз)

[10] Orda G., Khudaibergenov N., Sarsenbayeva Zh., Amanzhol S., Mursalimova N. The December Revolt Statement (Description) in Kazakh Literature. - Opción, 2019. - Año 35, No.89. URL:http://www.scopus.com/inward/record.url. 179-194. (анг)

[11] Пиралиева Г. Некоторые проблемы психологии в художественной литературе (цветовое зрение, невербальные жесты, материальный мир). - Алматы, 2003. - 258 с. (каз)

[12] Скафтымов А. О психологизме в творчестве Стендаля и Толстого. - Москва, 1972. 288 c. (рус)

[13] Страхов И. Психологический анализ в литературном творчестве: В 2 ч. - Саратов, (1973). - Ч.1. - 183 с. (рус)

[14] Фрейд 3. Введение в психоанализ. - Москва, 1989. - 456 с. (рус)

[15] Юнг К. Сознание и бессознательное. - Москва, 2007. - 188 с. (рус)

[16] Литература XXI века. - Алматы: Арыс, 2012. - 640 с. (каз)

\section{References:}

[1] Bursov B. (1979). Personality of Dostoevsky. - Leningrad, 680 p.

[2] Vygotsky L. (1968). Psychology of Art. - Moscow, - 345 p.

[3] Ginzburg L. (1977). On psychological prose. - Moscow, - $350 \mathrm{p}$.

[4] Dadebaev Zh., Bisenbaev P., Karibozov E. Psychopoetics of Chingiz Aitmatova. // Bulletin of KazNU, Series "Philology", (2016). - Volume 159. - No. 1. - P. 35-38.

[5] Konys L. (2013). Songs of Shaharbanua. - Almats, - 192 p.

[6] Likhachev D. (1968). The inner world of a work of art. - Questions of literature, - №8. - P. 7487.

[7] Malbakov M., Esenova K., Khinayat B. (2011). Dictionary of the Kazakh literary language.

Fifteen volumes. - Almaty, - T.14. - 800 p.

[8] Mukanova R. (2008). I'm under the roof. Stories and dramas. - Almaty, - 285 p.

[9] Omarova M. (2009). Maternal life. Prose. - Almaty, - 126 p.

[10] Orda G., Khudaibergenov N., Sarsenbayeva Zh., Amanzhol S., Mursalimova N. (2019). The December Revolt Statement (Description) in Kazakh Literature. - Opción, - Año 35, - No.89. URL:http://www.scopus.com/inward/record.url. 179-194.

[11] Piralieva G. (2003). Some problems of psychology in fiction (color vision, non-verbal gestures, the material world). - Almaty, - $258 \mathrm{p}$. 
[12] Skaftymov A. (1972). On psychologism in the works of Stendhal and Tolstoy. - Moscow, $288 \mathrm{p}$.

[13] Strakhov I. (1973). Psychological analysis in literary creativity: In 2 hours - Saratov, - Part 1. $-183 \mathrm{p}$.

[14] Freud Z. (1989). Introduction to psychoanalysis. - Moscow, - 456 p.

[15] Jung K. (2007). Consciousness and the unconscious. - Moscow, - 188 p.

[16] Literature of the XXI century. (2012). - Almaty: Arys, - 640 p. 